\title{
COMPARATIVE ANALYSIS OF RESULTS OF NUMERICAL SIMULATION OF CYBER-PHYSICAL BIOSENSOR SYSTEMS ON THE BASIS OF LATTICE DIFFERENTIAL EQUATIONS
}

\author{
Andriy Sverstiuk
}

\section{Horbachevsky Ternopil National Medical University Ternopil, Ukraine}

\begin{abstract}
Summary. The article deals with the comparative analysis of the results of numerical modeling of mathematical models of cyber-physical biosensor systems on hexagonal and rectangular lattices using lattice differential equations. The main attention is given to the mathematical description of the discrete population dynamics in combination with the dynamic logic of the studied models. The lattice differential equations with delay are proposed to simulate antigen-antibody interaction within hexagonal and rectangular biopixels. Appropriate spatial operators have been used to model the interaction between biopixels similar to the phenomenon of diffusion. The paper presents the results of numerical simulations in the form of phase plane images and lattice images of the probability of antigen to antibody binding in the biopixels of cyberphysical biosensor systems for antibody populations relative to antigen populations. The obtained experimental results make it possible to carry out a comparative analysis of the stability of mathematical models of cyberphysical immunosensory systems on hexagonal and rectangular lattices using lattice differential equations. It is concluded that at a constant delay value [0,0.25) for the model on the hexagonal lattice and [0,0.22] when using a rectangular lattice, respectively, the solutions of the mathematical models studied tend to non-identical endemic states, which in this case are stable foci. The results of the phase diagrams of antigen populations, antibodies and lattice images of the likelihood of antigen binding to antibodies in the biopixels of cyberphysical biosensor systems conclude that at a constant delay value 0,25 (in the case of a hexagonal lattice) and 0.23 (in the case of a rectangular lattice), Hopf bifurcation occurs and all subsequent trajectories correspond to stable boundary cycles for all pixels. The obtained experimental results make it possible to perform a comparative analysis of the stability of mathematical models of cyberphysical biosensor systems on hexagonal and rectangular lattices using lattice differential equations.
\end{abstract}

Key words: cyber-physical system, biosensor, continuous dynamics, dynamic logic, differential equations.

https://doi.org/10.33108/visnyk_tntu2019.03.123

Received 20.09.2019

Problem statement. Today, the concept of creating cyberphysical systems (CPS) for various spheres of human activity is actively developing. CPS are considered as intelligent systems, in which physical objects, external devices, processors, network equipment are integrated. The main purpose of CPS creation is to monitor the behavior of physical objects as components of such systems in real time. These are systems in which cybernetic means (measuring, computing, communication, control, executive) interact with physical processes in arbitrary objects [1].

Analysis of known research results. Cyberphysics of the system are identified with the manifestation of the fourth industrial revolution that is taking place in the modern world [2]. Thus, there is also the physical possibility of using Internet of Things (IoT) technologies where signals from sensors and measuring instruments need to be used. Thus, more publications are emerging in the literature [3], which attract attention to modern concepts and offer new innovative solutions. A. Plattser proposed an approach based on «dynamic logic», where cyberphysical systems are described and analyzed [4], [5]. In these works, there are hybrid programs (HP) in a simple programming language with simple semantics. HP allow the programmer to access directly the real values of variables representing real values and determine their dynamics. 
The goal of the work. Perform comparative analysis of results of numerical modeling of mathematical models of cyberphysical biosensory systems on rectangular and hexagonal lattice using lattice differential equations.

The investigated models have the capabilities to control and calculate signals of object control in various branches of the national economy, in particular in medicine and fully reveal their potential in the development of cyberphysical biosensor systems.

Setting objectives. When analyzing the results of numerical modeling of mathematical models of cyberphysical biosensory systems on a rectangular and hexagonal lattice using lattice differential equations, it is necessary to take into account spatial-temporal properties of devices in which they are used. With respect to spatial organization, the models examined should be based on certain discrete structures, which will take into account the interaction of biosensor pixels. In continuous space, models must describe processes known as population dynamics. That is why the problem is the analysis of the results of numerical modeling of mathematical models of cyberphysical biosensory systems on a rectangular and hexagonal lattice using lattice differential equations.

Results of the research. With the increasing pace of life and the need for more accurate methods of monitoring different parameters, interest in biosensors is growing in science and industry. Biosensors are alternatives to known measurement methods characterized by poor selectivity, high cost, poor stability, slow response and can often only be performed by highly trained personnel. This is a new generation of sensors that use a biological material in the design that provides very high selectivity and allows fast and simple measurements [6], [7].

Cellular biosensors can be used to quantify body infection by certain electrochemical or optical phenomena [8]. describes a cell biosensor that uses electrochemical impedance spectroscopy. This biosensor is designed to count human CD4 + cells. The probing region of this biosensor includes electrode pixels, each of which is compared to the size of the $\mathrm{CD} 4+$ cell that is entangled by the electrode pixels. They find themselves by observing informative changes per pixel. The «On» or «Off» state of the electrode pixel indicates that one CD4 + cell is detected. Thus, in order to calculate the CD4 + cells, it is necessary to sum the electrode pixels in the «On» state.

This general approach to quantitative cell detection is used to model imunosensornea of a system that is based on the phenomenon of fluorescence. Immunosensor [9] is a subgroup of biosensors in which an immunochemical reaction is associated with a transducer. The principle of operation of all immunosensors is specific molecular recognition of antigens by antibodies to form a stable complex.

Cyber-physical biosensory system (CPBSS). The definition of the term «Cyber-Physical Sensor System (CPBSS)» is given in [10]. This definition was introduced for industrial applications of sensors. The common definition of CPBSS provides for «a higher degree of combination, distribution of the system, use of built-in systems in the field of automation and compliance with existing standards». The approach was used to characterize CPBSS (see Fig. 1), which allows to perform its numerical simulation.

According to [10], definitions and schemes for the CPBSS are used to define the CPBSS. CPBSS converts physically measured immunological indicators into digital information, which allows to carry out signal processing in time using certain algorithms. Also interact with your own capabilities, requirements, internal data, and internal tasks in terms of propagating to the same or higher level of the hierarchy.

CPBSS (external rectangle in Fig. 1) is based on the concept of cyber-physical system (CPS) taking into account the peculiarities of intelligent immunosensor. With additional skills (dashed line in Fig. 1), the sensor expands to CPBSS. This provides more diagnostic information about the object of research. 


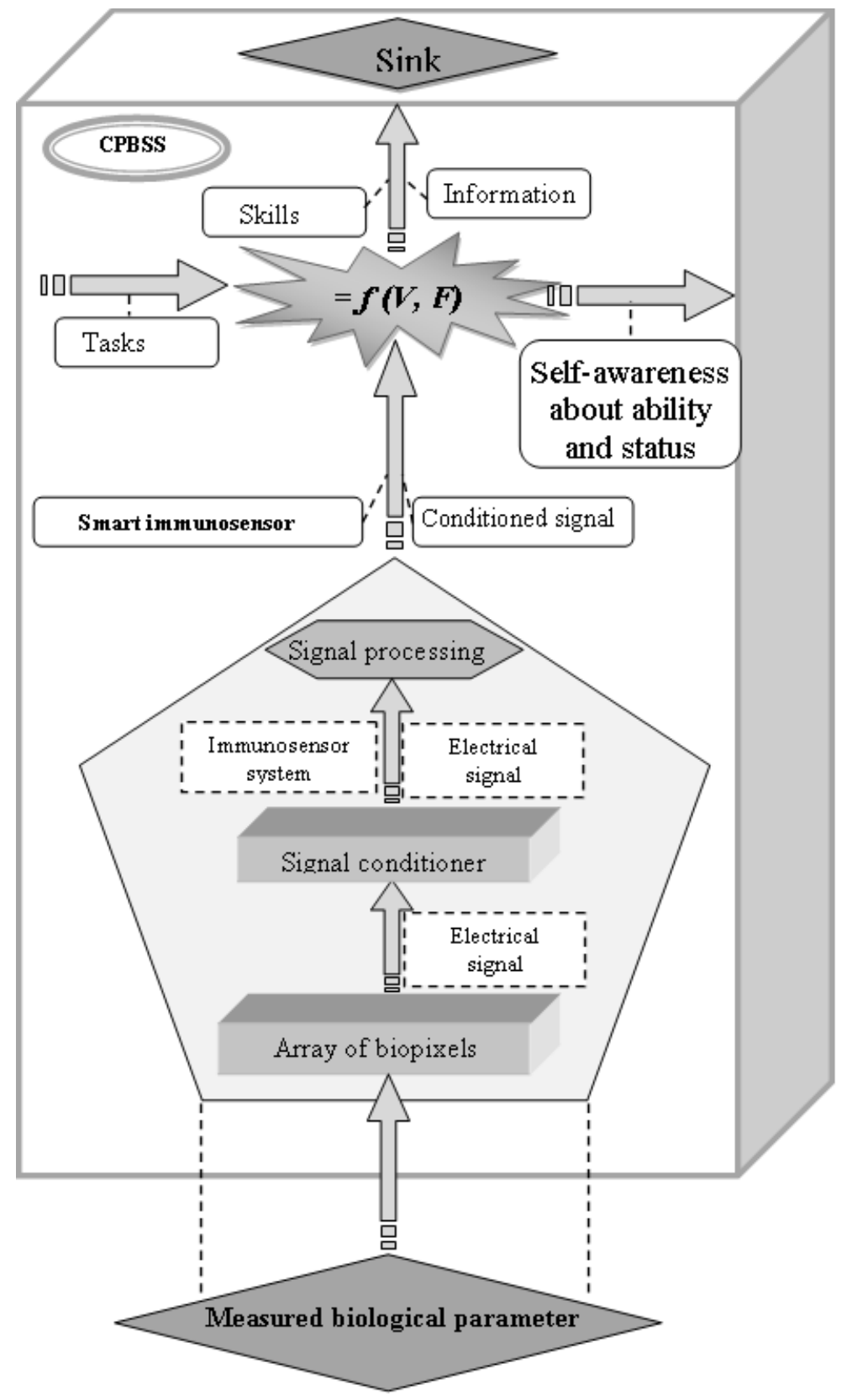

Figure 1. Functional scheme of CPBSS

CPBSS refers to highly intellectual of information systems. They use an accessible set of interfaces that provide fast and reliable status information and internal system data that should be available to other CPS. According to [10] the CPBSS as a self-organizing system, requires comprehensive knowledge of its own dynamic structure and infrastructure of the common system. For this purpose, it is necessary to define types of imunosensory devices, taking into account their functional application. For example, immunosensors can be used to assess critical conditions in cardiovascular disease, insulin values in blood glucose measurement, and quantify certain Pharmactic compounds.

Work [10] proposes a common structure for the CPBSS. When this scheme is used in the case of biosensors, three directions of viocremes can be used: general information on the immunosensor; measurements of immunological indicators and skills, conversion of units and calibration; interaction with other immunosensors. Thus, certain methods for describing the 
immunosensor are contemplated. CPBSS research uses the R programming language Despite the wide variety of programming languages used in CPS development (Assembly, C, C++, D, Java, JavaScript, Python, Ada, etc. [11]), $\mathrm{R}$ is now widely used in many machine learning and data visualization industries.

Continuous dynamics of studied CPBSS. A mathematical description is used for the continuous dynamics of the studied CPBSS using differential equations with lag.

A mathematical model CPBSS on a hexagonal lattice with used lattice differential equations with lag. The CPBSS model based on hexagonal lattice from used lattice differential equations is considered. At that, cubic coordinate system [12] is used for numbering of biopixelive $(i, j, k), i, j, k=-\overline{N, N}, i+j+k=0$.

Let's denote $V_{i, j, k}(t)$ as antigen concentration, $F_{i, j, k}(t)$ - antibody concentration in biopixels $(i, j, k) ; i, j, k=\overline{-N, N}, i+j+k=0$.

The model is based on such biological assumptions for an arbitrary biopixel $(i, j, k)$.

1. There is some fertility constant $\beta>0$ for the antigen population.

2. Antigens are neutralized by antibodies at some probabilistic rate $\gamma>0$.

3. The antigen population seeks some facet of saturation at a rate $\delta_{v}>0$.

4. There is some diffusion of antigens from six adjacent pixels $(i+1, j, k-1)$, $(i+1, j-1, k), \quad(i, j-1, k+1), \quad(i-1, j, k+1), \quad(i-1, j+1, k),(i, j+1, k-1)$, (Fig. 1) at the diffusion rate $D \Delta^{-2}$, where $D>0$ and $\Delta>0$ is the distance between pixels.

5. There 's some constant antibody mortality $\mu_{f}>0$.

6. As a result of the immune response, the density of antibodies increases at a probabilistic rate $\eta \gamma$.

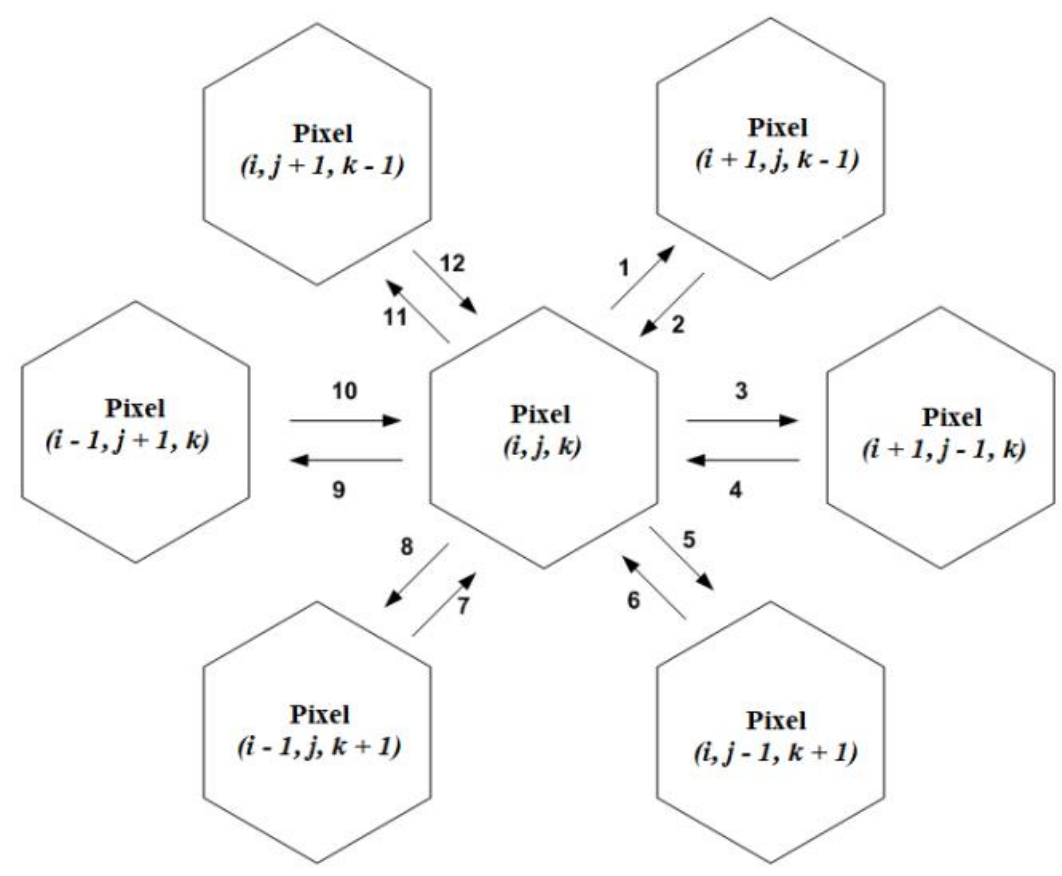

Figure 2. A hexagonal lattice that binds six adjacent pixels in a model using cubic coordinates:

$$
1,3,5,8,9,11-\left(\frac{D}{\Delta^{2}} v_{i, j, k}(t)\right) ; 2-\left(\frac{D}{\Delta^{2}} v_{i+1, j, k-1}(t)\right) ; 4-\left(\frac{D}{\Delta^{2}} v_{i+1, j-1, k}(t)\right) ;
$$




$$
\begin{aligned}
6-\left(\frac{D}{\Delta^{2}} v_{i, j-1, k+1}(t)\right) & ; 7-\left(\frac{D}{\Delta^{2}} v_{i-1, j, k+1}(t)\right) ; 10-\left(\frac{D}{\Delta^{2}} v_{i-1, j+1, k}(t)\right) ; \\
12 & -\left(\frac{D}{\Delta^{2}} v_{i, j+1, k-1}(t)\right)
\end{aligned}
$$

7. The antibody population tends to achieve some level of saturation at a rate $\delta_{f}>0$.

8. The immune response comes with some constant time delay $\tau>0$.

On this basis we consider a very simple construction of the late antigen-antibody model for the hexagonal biopixel array, which is based on the well-known Marchuk model [13-15] and uses the spatial operator $\hat{S}$ proposed in [16] (additional information p. 10).

$$
\begin{gathered}
\frac{d V_{i, j, k}(t)}{d t}=\left(\beta-\gamma F_{i, j, k}(t-\tau)-\delta_{v} V_{i, j, k}(t-\tau)\right) V_{i, j, k}(t)+\hat{S}\left\{V_{i, j, k}\right\} \\
\frac{d F_{i, j, k}(t)}{d t}=\left(-\mu_{f}+\eta \gamma V_{i, j, k}(t-\tau)-\delta_{f} F_{i, j, k}(t)\right) F_{i, j, k}(t) .
\end{gathered}
$$

The model (1) is defined by the initial functions (2):

$$
\begin{gathered}
V_{i, j, k}(t)=V_{i, j, k}^{0}(t) \geq 0, \quad F_{i, j, k}(t)=F_{i, j, k}^{0}(t) \geq 0, \quad t \in[-\tau, 0), \\
V_{i, j, k}(0), \quad F_{i, j, k}(0)>0 .
\end{gathered}
$$

For the hexagonal array, discrete diffusion is used for the spatial operator.

$$
\hat{S}\left\{V_{i, j, k}\right\}=\left\{\begin{array}{c}
D \Delta^{-2}\left[V_{i+1, j, k-1}+V_{i+1, j-1, k}+V_{i, j-1, k+1}+V_{i-1, j, k+1}+V_{i-1, j+1, k}+V_{i, j+1, k-1}-6 n V_{i, j, k}\right] \\
i, j, k \in \overline{-N+1, N-1}, \quad i+j+k=0 .
\end{array}\right.
$$

Each colony is exposed to antigens produced in six adjacent biopixels, which are separated by equal distances $\Delta$.

A mathematical model CPBSS of on a rectangular lattice with used lattice differential equations with lag. The mathematical model CPBSS on a rectangular lattice with used lattice differential equations with delay is considered in [17] is as follows:

$$
\begin{gathered}
\frac{d V_{i, j}(t)}{d t}=\left(\beta-\gamma F_{i, j}(t-\tau)-\delta_{\nu} V_{i, j}(t-\tau)\right) V_{i, j}(t)+\hat{S}\left\{V_{i, j}\right\} \\
\frac{d F_{i, j}(t)}{d t}=\left(-\mu_{f}+\eta \gamma V_{i, j}(t-\tau)-\delta_{f} F_{i, j}(t)\right) F_{i, j}(t) .
\end{gathered}
$$

The names and values of the corresponding model values (4) are given above. Model (4) is defined by initial functions (5):

$$
\begin{gathered}
V_{i, j}(t)=V_{i, j}^{0}(t) \geq 0, \quad F_{i, j}(t)=F_{i, j}^{0}(t) \geq 0, \quad t \in[-\tau, 0), \\
V_{i, j}(0), \quad F_{i, j}(0)>0 .
\end{gathered}
$$


For a square array $N \times N$ the following discrete diffusion is used for a spatial operator $\hat{S}\left\{V_{i, j}\right\}$.

$$
\hat{S}\left\{V_{i, j}\right\}=\left\{\begin{array}{l}
D \Delta^{-2}\left[V_{1,2}+V_{2,1}+V_{i, j-1}-2 n V_{1,1}\right] \quad i, j=1 \\
D \Delta^{-2}\left[V_{2, j}+V_{1, j-1}+V_{1, j+1}+V_{i, j+1}-3 n V_{i, j}\right] \quad i=1, j \in \overline{2, N-1} \\
D \Delta^{-2}\left[V_{1, N-1}+V_{2, N}-2 n V_{1, N}\right] i, j \in \overline{2, N-1} \\
D \Delta^{-2}\left[V_{i-1, N}+V_{i+1, N}+V_{i, N-1}-3 n V_{i, N}\right] \quad i \in \overline{2, N-1}, j=N \\
D \Delta^{-2}\left[V_{N-1, N}+V_{N, N-1}-2 n V_{N, N}\right] i=N, j=N \\
D \Delta^{-2}\left[V_{N-1, j}+V_{N, j-1}+V_{N, j+1}+V_{i, j+1}-3 n V_{N, j}\right] \quad i=N, j \in \overline{2, N-1} \\
D \Delta^{-2}\left[V_{N-1,1}+V_{N, 2}-2 n V_{N, 1}\right] \quad i=N, j=1 \\
D \Delta^{-2}\left[V_{i-1,1}+V_{i+1,1}+V_{i, 2}-3 n V_{i, 1}\right] \quad i \in \overline{2, N-1}, \quad j=1 \\
D \Delta^{-2}\left[V_{i-1, j}+V_{i+1, j}+V_{i, j-1}+V_{i, j+1}-4 n V_{i, j}\right] \quad i, j \in \overline{2, N-1}
\end{array}\right.
$$

Each colony is exposed to antigens produced in four adjacent biopixels. Two colonies are considered in each direction, which are separated by equal distances $\Delta$.

Dynamic logical simulation of CPBSS using the example of a mathematical model of CPBSS on a hexagonal lattice with used lattice differential equations with lag. In order to model the dynamic logic of the studied CPBSS, we use the syntax proposed by A. Platzer for the common CPS [4]. For CPS, the programming language of hybrid programs (HP) is used, which has more features than differential equations. The first level of HP are dynamic programs that are defined by the following grammar

$$
\begin{gathered}
a::=\frac{d V_{i, j, k}(t)}{d t}=\left(\beta-\gamma F_{i, j, k}(t-\tau)-\delta_{v} V_{i, j, k}(t-\tau)\right) V_{i, j, k}(t)+\hat{S}\left\{V_{i, j, k}\right\}, \\
\frac{d F_{i, j, k}(t)}{d t}=\left(-\mu_{f}+\eta \gamma V_{i, j, k}(t-\tau)-\delta_{f} F_{i, j, k}(t)\right) F_{i, j, k}(t) \& \Phi_{t} .
\end{gathered}
$$

In formula (4) $\Phi_{t}$ is an evolutionary domain constraint in the form of a first order logic formula

$$
\begin{gathered}
\Phi_{t}^{\text {def }} \equiv V^{\min } \leq V_{i, j, k}(n) \leq V^{\max }, \\
\wedge F^{\min } \leq F_{i, j, k}(n) \leq F^{\max } \wedge i, j, k=\overline{-N, N} \wedge t>0, \\
i+j+k=0 .
\end{gathered}
$$

As a result of the binding of antigens to antibodies in the imunopixel $(i, j, k)$ a fluorescence phenomenon occurs. The functioning of the imunopixel is determined by two states. Namely, $s_{f l}$ is a fluorescence state and $s_{n o n f l}$ is one of the non-fluorescent states. 
The fluorescence intensity is proportional to the number of contacts between antigens and antibodies, i.e. The pixel is assumed to be in a fluorescence state if

$$
k_{f l} V_{i, j, k}(t) F_{i, j, k}(t) \geq \Theta_{f l},
$$

where $\Theta_{f l}>0$ is some binding threshold at which the fluorescence phenomenon occurs.

By using in the syntax of first-order logic the ratio of pleasure $s \mid=L$ for the formula of first-order logic $L$ and state $S$, one can define for specific points $(i, j, k) ; i, j, k=-\overline{N, N}$, $i+j+k=0$ states $s_{f l}$ and $s_{n o n f l}$ as

$$
\begin{gathered}
s_{f t} \mid=k_{f l} V_{i, j, k}(n) F_{i, j, k}(n) \geq \Theta_{f l}, \\
s_{\text {nonfl }} \mid=k_{f l} V_{i, j, k}(n) F_{i, j, k}(n)<\Theta_{f l} .
\end{gathered}
$$

Discrete changes occur in computer programs when they take on new values for variables. This situation occurs when a fluorescence phenomenon occurs in the pixel $(i, j, k)$, $i, j, k=-\overline{N, N}, i+j+k=0$. In the fluorescence state $s_{f l, i, j, k}$ the variable is set to 1 . This leads to a discrete, hopping as the value $s_{f l, i, j, k}$ changes instantaneously.

In the study of resistance of the mathematical model of immunosensor on the hexagonal lattice, constant states are calculated: stable state without antibodies, stable state without antigens and antibodies, identical and identical endemic stable states.

In general, the equilibrium state $\varepsilon_{i, j, k} \equiv\left(V_{i, j, k}, F_{i, j, k}\right), \quad i, j, k=-\overline{N, N}, \quad i+j+k=0$ for system (1) can be found as a solution to an algebraic system:

$$
\begin{gathered}
\left(\beta-\gamma F_{i, j, k}^{*}-\delta_{v} V_{i, j, k}^{*}\right) V_{i, j, k}^{*}+\hat{S}\left\{V_{i, j, k}^{*}\right\}=0 \\
\left(-\mu_{f}+\eta \gamma V_{i, j, k}^{*}-\delta_{f} F_{i, j, k}^{*}\right) F_{i, j, k}^{*}=0 .
\end{gathered}
$$

Considering $\left(V_{i, j, k}, F_{i, j, k}\right), i, j, k=\overline{-N, N}, i+j+k=0$, there are such cases.

Stable state without antigens and antibodies $\varepsilon_{i, j, k}^{0,0} \equiv \varepsilon^{0,0}=(0,0), i, j, k=\overline{-N, N}$, $i+j+k=0$.

Stable state without antibodies $\varepsilon_{i, j, k}^{*, 0} \equiv \varepsilon^{*, 0}=\left(\frac{\beta}{\delta_{v}}, 0\right), i, j, k=\overline{-N, N}, i+j+k=0$.

For an identical endemic steady state, consider the case where $V_{i, j, k} \equiv V^{\text {ident }}>0$, $i, j, k=\overline{-N, N}, i+j+k=0, \quad\left(\hat{S}\left\{V_{i, j, k}\right\} \equiv 0\right) . \quad$ Then we get a stable state in which $\varepsilon_{i, j, k} \equiv \varepsilon^{\text {ident }}=\left(V^{\text {ident }}, F^{\text {ident }}\right)$,

where $V^{\text {ident }}=\frac{\beta \delta_{f}+\gamma \mu_{f}}{\eta \gamma^{2}+\delta_{v} \delta_{f}}, F^{\text {ident }}=\frac{-\mu_{f} \delta_{v}+\eta \gamma \beta}{\eta \gamma^{2}+\delta_{v} \delta_{f}}$. 
That is, if $-\mu_{f} \delta_{v}+\eta \gamma \beta>0$, then $\varepsilon^{\text {ident }}$ is an endemic condition.

To calculate identical endemic stationary state in general it is necessary to solve algebraic system (10) and find endemic stable state. The last kind of constant state is called identical to the constant state $\varepsilon^{\text {non-ident }}=\left(V_{i, j, k}^{\text {non-ident }}, F_{i, j, k}^{\text {non-ident }}\right), i, j, k=\overline{-N, N}, \quad i+j+k=0$. In case if all $\left(V_{i, j, k}^{\text {non-ident }}, F_{i, j, k}^{\text {non-ident }}\right)>0$, then $\varepsilon^{\text {non-ident }}$ is an endemic condition. The $V^{\text {ident }}$ and $F^{\text {ident }}$ values can be used as guess values for numerical methods of solving a nonlinear algebraic system (10).

The $\mathrm{R}$ programming language and $\mathrm{R}$ Studio development environment have been used for the purpose of computer modeling CPBSS. This is because, despite the wide variety of programming languages used in the development of CPS (Assembly, C, C++, D, Java, JavaScript, Python, Ada, etc. [14]), $\mathrm{R}$ is now widely used in many machine learning industries and will involve further research. Visualization of data in computer modeling is carried out by means of a ggplot package.

Results of numerical simulation of the mathematical model of CPBSS on hexagonal lattice with used lattice differential equations with lag.

Numerical experiments based on computer simulation were carried out taking into account an integer natural number $N$ that characterizes the number of pixels in the hexagonal lattice. The model (1)-(3) at $N=4, \quad \beta=2 \mathrm{~min}^{-1}, \gamma=2 \frac{\mathrm{ml}}{\mathrm{min} \cdot \mu \mathrm{g}}, \mu_{f}=1 \mathrm{~min}^{-1}, \quad \eta=\frac{0.8}{\gamma}$, $\delta_{v}=0.5 \frac{\mathrm{ml}}{\mathrm{min} \cdot \mu \mathrm{g}}, \delta_{f}=0.5 \frac{\mathrm{ml}}{\mathrm{min} \cdot \mu \mathrm{g}}, n=0.9, D=0.2 \frac{\mathrm{nm}^{2}}{\mathrm{~min}}, \Delta=0.3 \mathrm{~nm}$.

Numerical modeling of the CPBSS mathematical model on a hexagonal lattice with used lattice differential equations with lag was implemented for different values $\tau$.

The long-term behavior of the model (1)-(3) at $\tau=0.05, \tau=0.25, \tau=0.287$, with a set of parameter values as shown above (Fig. $3(\mathrm{a}-\mathrm{c})$ ) was analyzed. We observe qualitative changes in the behavior of biopixelive and CPBSS models on the hexagonal lattice as a whole.

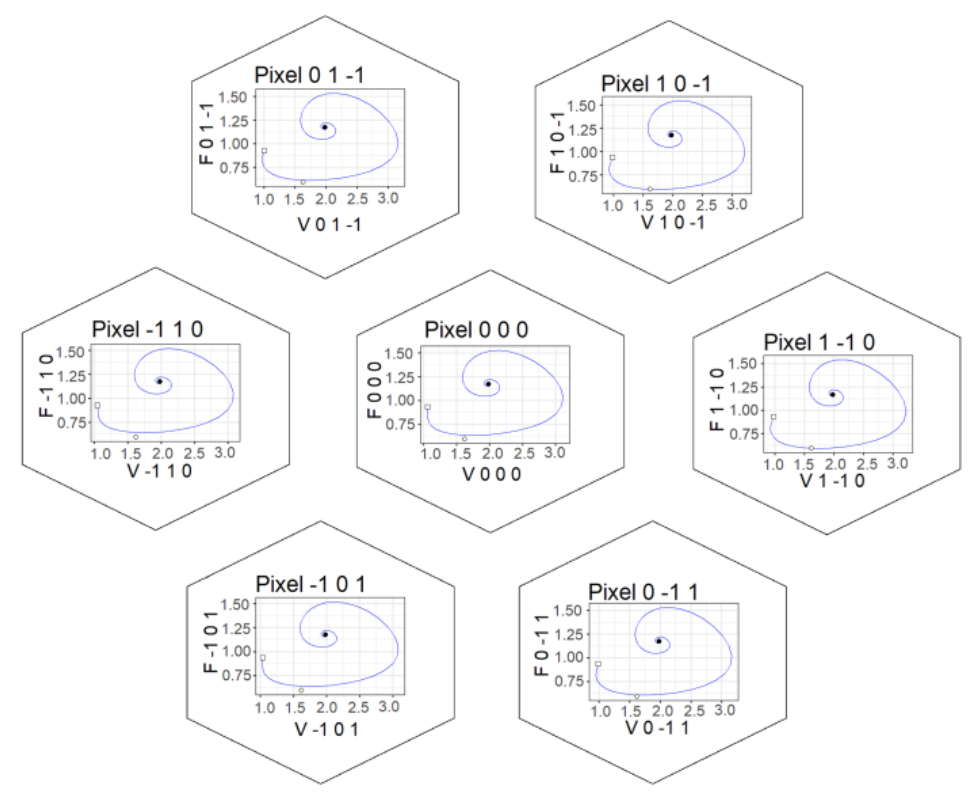

a) 


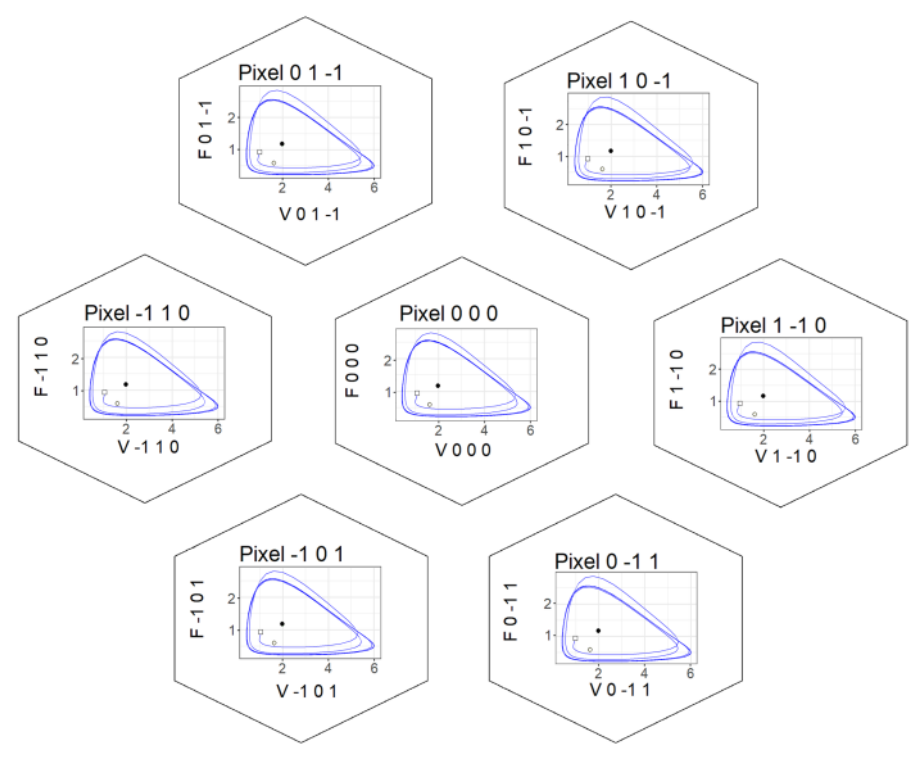

b)

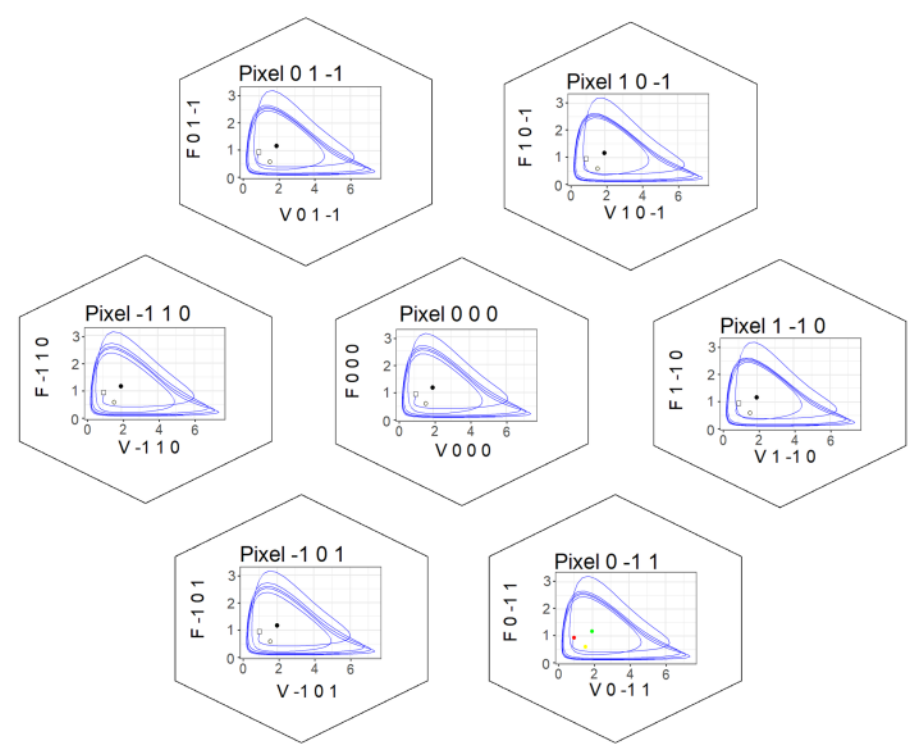

c)

Figure 3. Results of numerical simulation system (1) at

a) $-\tau=0.05, b)-\tau=0.25, c)-\tau=0.287$

Image of phase planes in coordinates $\left(V_{i, j, k}, F_{i, j, k}\right)$ for a pixel $(0,0,0)$ and its six adjacent pixels. Marking: $\square-$ indicates initial state, $\circ-$ identical steady state, $\bullet-$ nonidentical steady state.

For the computer simulation of the CPBSS model under study, lattice graphs were used, showing for each pixel the probability of antigens contacting antibodies as $V_{i, j, k} \times F_{i, j, k}$ in $\tau=0.05, \tau=0.25, \tau=0.287$, which are shown in Figure $4(\mathrm{a}-\mathrm{c})$. 

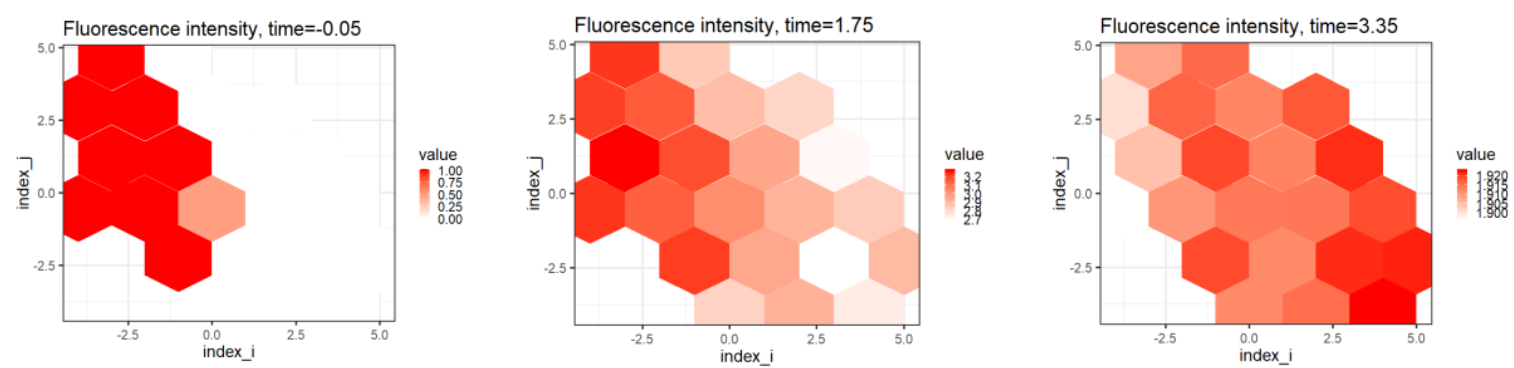

a)
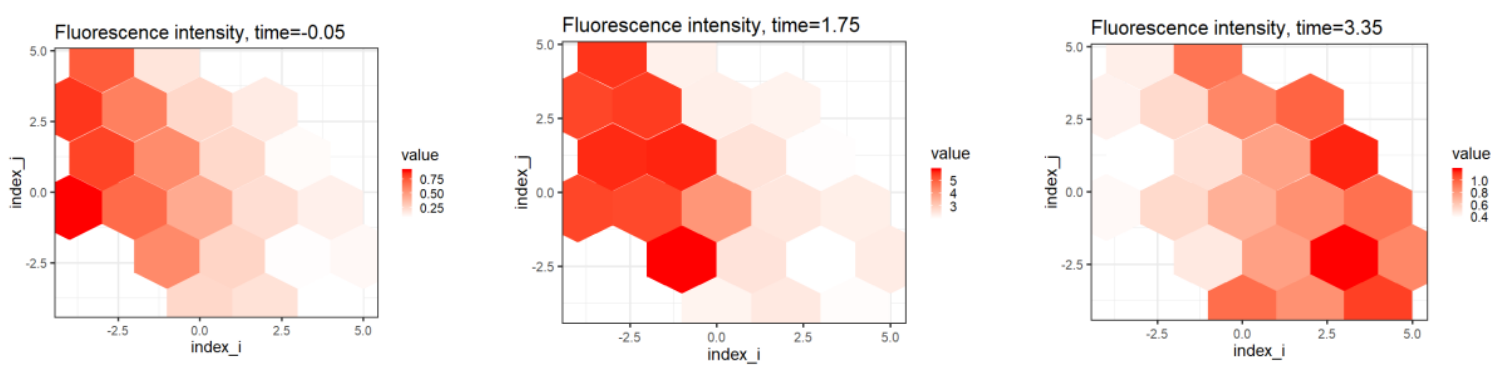

b)
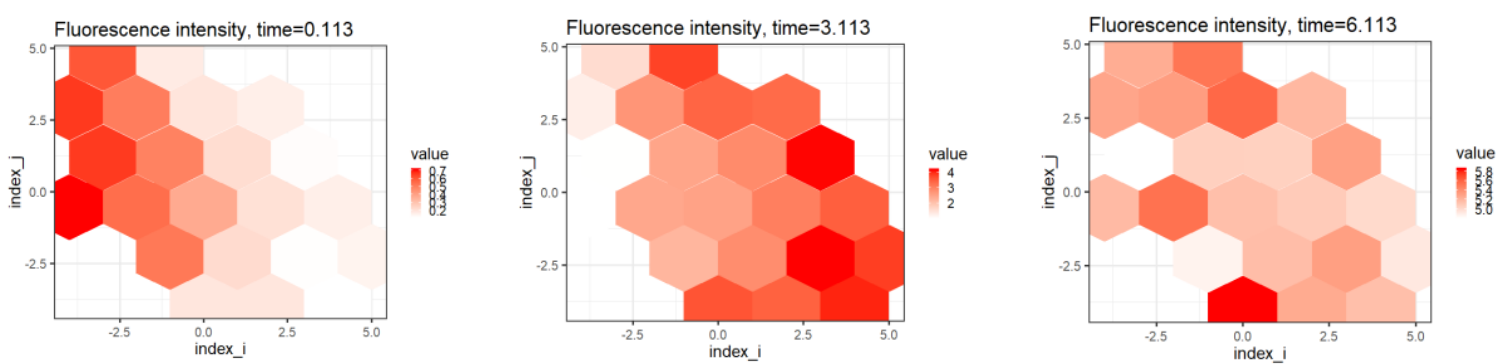

c)

Figure 4. Lattice images of the probability of antigen binding to antibodies in system pixels (1) at

$$
\tau=0.05 \text { (a); } \tau=0.25 \text { (b); } \tau=0.287 \text { (c) }
$$

By analyzing phase diagrams of antigen populations, antibodies (Fig. 3 a) and lattice images of the probability of antigen-antibody linkages in CPBSS biopixels (Fig. 4 a), it can be concluded that in $\tau=0.05$ solving the system (1) tends to be identical to the endemic state, which in this case is a sustained focus. Such dependencies are observed for all biopixelives of the CPBSS model on the hexagonal lattice using lattice differential equations with lag at $\tau \in[0,0.25$ ) (Fig. 3 a, 4 a).

By analyzing phase diagrams of antigen populations, from the antibodies (Fig. $3 \mathrm{~b}$ ) lattice images of the probability of antigen-antibody links in CPBSS biopixels (Fig. 4 b), it can be concluded that in the emerging Hopf bifurcation and all further paths correspond to stable limit cycles for all points (Fig. 3 b, 4 b). To theorize the occurrence of Hopf bifurcation, it is necessary to calculate a suitable pair of purely imaginary solutions to the characteristic equation of the linearized system (1). Numerical simulation results are consistent with theoretical results based on Hopf bifurcation theorem [18]. At the same time, the solution of the system (1) seeks a stable limit cycle with two local extremes (one local maximum and one local minimum) in the cycle.

Results of numerical simulation of the mathematical model of CPBSS on a rectangular lattice with used lattice differential equations with lag. Model (4)-(6) at $N=4, \beta=2 \mathrm{~min}^{-1}$, 
$\gamma=2 \frac{\mathrm{ml}}{\mathrm{min} \cdot \mu g}, \mu_{f}=1 \mathrm{~min}^{-1}, \eta=\frac{0.8}{\gamma}, \delta_{v}=0.5 \frac{\mathrm{ml}}{\mathrm{min} \cdot \mu g}, \delta_{f}=0.5 \frac{\mathrm{ml}}{\mathrm{min} \cdot \mu g}, n=0.9, D=0.2 \frac{\mathrm{nm}^{2}}{\mathrm{~min}}$, $\Delta=0.3 \mathrm{~nm}$.

Computer simulations were implemented for different values $\tau$. The long-term behavior of the model (4)-(6) is analyzed at $\tau=0.05, \tau=0.22, \tau=0.23 \tau=0.2865$, with a set of parameter values, which are presented above (Fig. 3-5). We see qualitative changes in the behavior of biopixelive and CPBSS models in general.
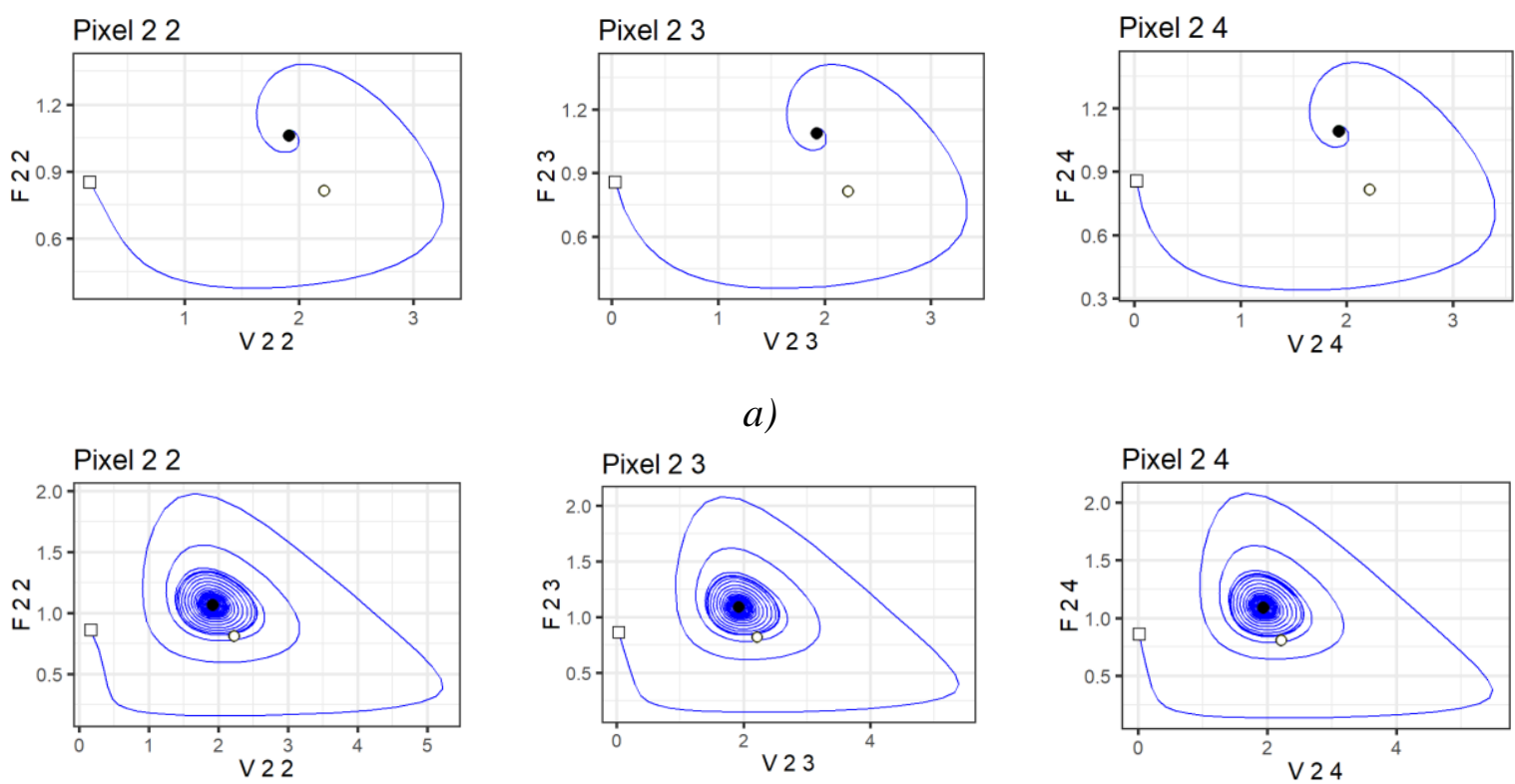

b)
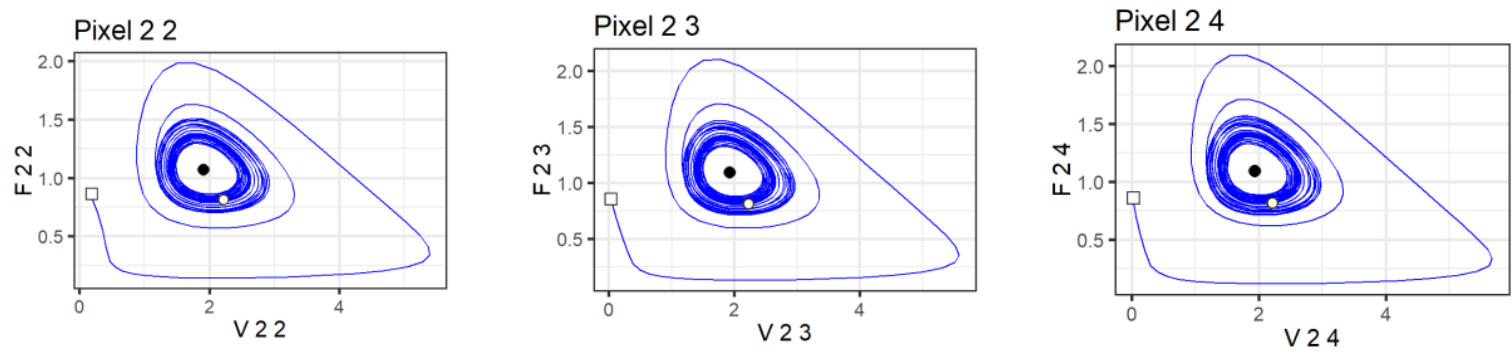

c)
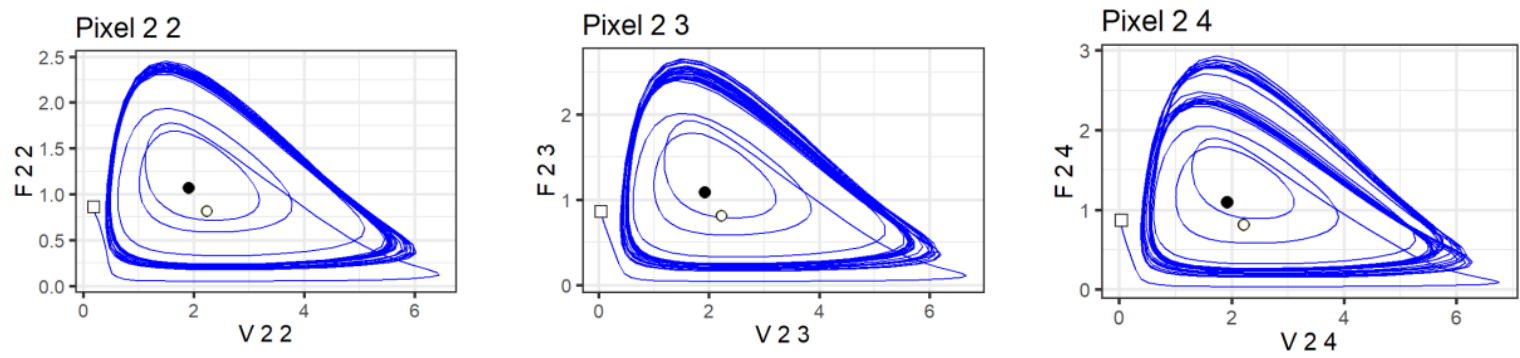

d)

Figure 5. The phase plane plots of the system (3) or antibody populations $F_{i, j}$, relative to populations of antigens $V_{i, j}$, as a result of numerical simulations at $\tau=0.05(a), \tau=0.22(b), \tau=0.23(c)$, $\tau=0.2865(d)$. Marking: $\square-$ indicates initial state, $\circ-$ identical steady state, $\bullet-$ nonidentical steady state 
Lattice graphs were used as the next step in the numerical simulation of CPBSS on a rectangular lattice. First, the corresponding graphs are constructed, on which for each pixel the probability of antigens contact with antibodies $V_{i, j, k} \times F_{i, j, k}$, as in $\tau=0.05, \tau=0.22, \tau=0.23$, $\tau=0.287$ are shown in Figure $4(\mathrm{a}-\mathrm{d})$.
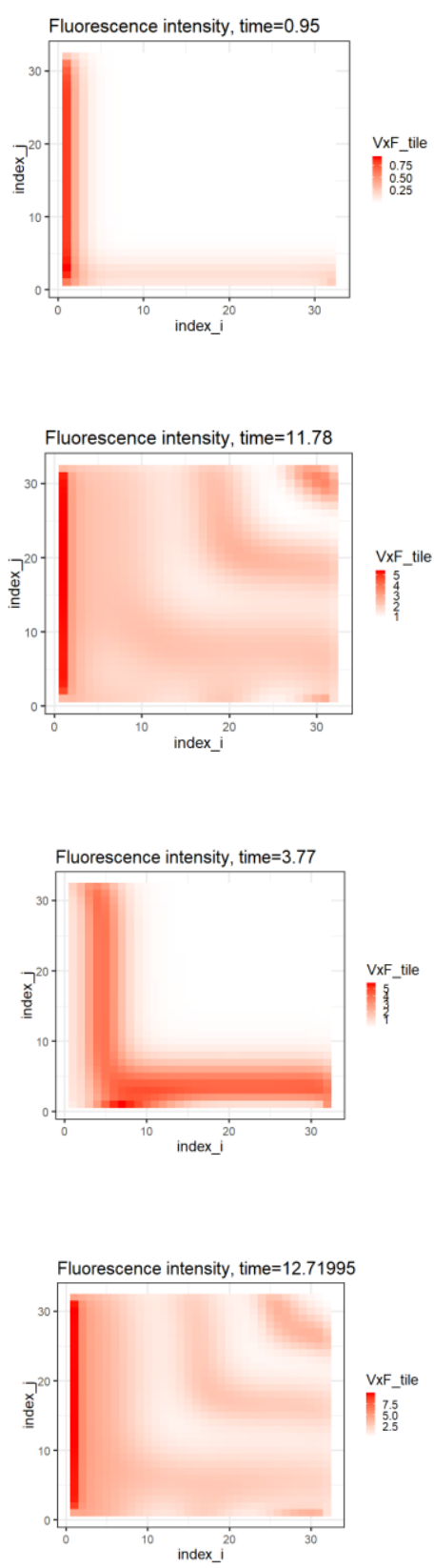

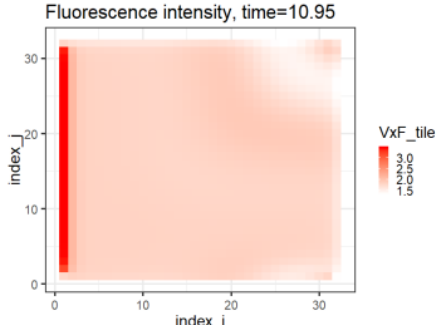

a)

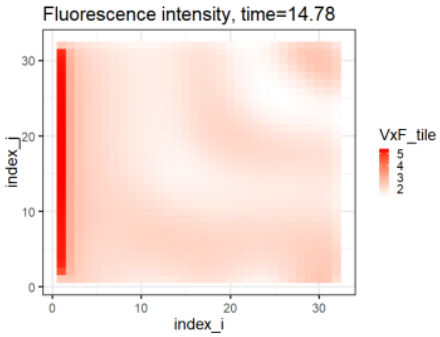

b)

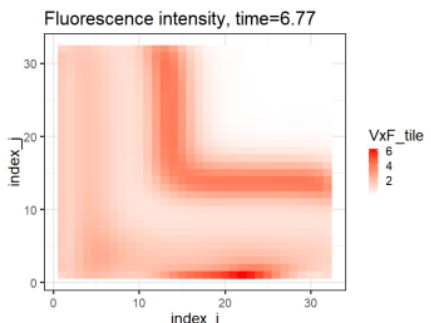

c)
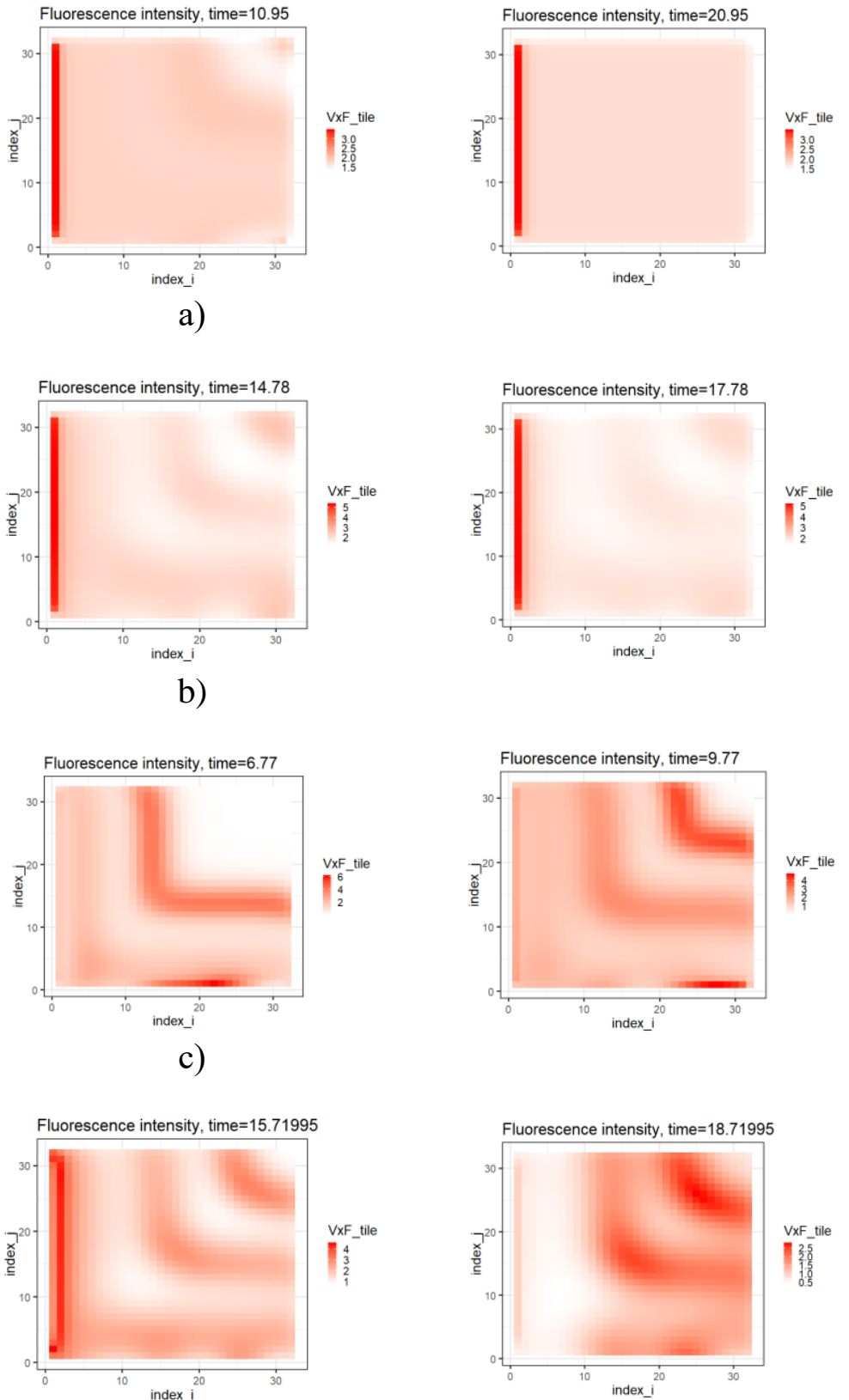

d) 
At a value $\tau$ close to 0.23 min., Hopf bifurcation occurs and further paths correspond to stable elipse-shaped limit cycles for all points (Fig. 3 (c)). For values $\tau \geq 0.2865$ we observe chaotic behavior relative to (Fig. 3 (d)).

Comparative analysis of results of numerical simulation of mathematical models of cyberphysical biosensory systems on hexagonal and rectangular lattice using lattice differential equations.

By comparing the results of numerical modeling of the studied mathematical models of cyberphysical biosensory systems in the form of phase diagrams of antigen populations, by antibodies (Fig. 3 a, 5 a) and lattice images of the probability of antigen connections to antibodies in CPBSS biopixels (Fig. 4 a, 6 a), it can be concluded that in $\tau=0,05$ the solution of the system (1) and (4) are resistant to non-endemic states. A similar relationship is observed for all biopixelives of the CPBSS model on the hexagonal lattice at $\tau \in[0,0.25$ ) (Fig. 3 a, 4 a), and in the case of using a rectangular lattice identical, the endemic state was observed at $\tau \in[0,0.22]$ (Fig. 5 a, 6 a).

According to the obtained results of phase diagrams of antigen populations, according to antibodies (Fig. 3 b) and lattice images of the probability of antigens binding to antibodies in CPBSS biopixels, it can be concluded that in $\tau=0,25$ (in the case of hexagonal grating (Fig. $3 \mathrm{~b}, 4$ b)) and 0.23 (in the case of rectangular grating) (Fig. 5 b, 6 b)) Hopf bifurcation occurs and all further paths correspond to steady limit cycles for all points (Fig. 3 b, 4 b, 5 b, 6 b).

As the results of the numerical analysis showed, the probabilities of antigen-antibody connections in the biopixels of the models under study vary according to the laws of discrete dynamics. Analyzing the obtained results, it was concluded that when the value changes qualitatively the behavior of biopixelive and CPBSS changes.

Conclusions. In the work we carried out comparative analysis of models of CPBSS on hexagonal and rectangular lattice using lattice differential equations, for which purpose the general scheme of cyberphysical and sensory system proposed in the work was used [10]. The basic model was modified to take into account the features of biosensors, which are considered in the form of biopixel arrays. Each biopixel is seen as a cyberphysical system in order to account for the continuous dynamics of the immunological response. Lattice images in biopixels change according to the laws of discrete dynamics. The developed models take into account the interaction of biopixelive with each other by diffusion of antigens. The mathematical description of CPBSS contains discrete population dynamics, which is combined with dynamic logic, which is used for discrete events. The work uses a class of lattice differential equations with time lag, which model the interaction of antigens and antibodies in biopixels. Spatial operators model diffusion type interaction between biopixels. Dynamic mathematical modeling is not enough to simulate discrete dynamics in biosensors. To address this disadvantage, the dynamic logic syntax that has been proposed for cyberphysical Platzer systems has been used to describe the discrete states of biopixel as a result of fluorescence. The results of numerical modeling in the form obtained in the work allow to carry out analysis of stability and comparison of investigated models, taking into account delay in time. 
Comparative analysis of results of numerical simulation of cyber-physical biosensor systems on the basis of lattice differential equations

\section{References}

1. Lee E. A. Cyber physical systems: Design challenges. Center for Hybrid and Embedded Software Systems. URL: https://www2.eecs.berkeley.edu/Pubs/TechRpts/2008/EECS-2008-8.pdf.

2. Lee J., Bagheri B., Kao H.-A. A cyber-physical systems architecture for industry 4.0-based manufacturing systems. Manufacturing Letters. Vol. 3. P. 18-23. 2015. ISSN: 2213-8463. DOI: https://doi.org/10.1016/j.mfglet.2014.12.001. URL: http://www.sciencedirect.com/science/article/pii/S $221384631400025 X$.

3. Kim K.-D., Kumar P. R. Cyber-physical systems: A perspective at the centennial. Proceedings of the IEEE. Vol. 100. No. Special Centennial Issue. 2012. P. 1287-1308. DOI: 10.1109/jproc.2012.2189792. URL: https://doi.org/10.1109/jproc.2012.2189792.

4. Platzer A. Differential dynamic logic for hybrid systems. J. Autom. Reas. Vol. 41. No. 2. P. 143-189. 2008. ISSN: 0168-7433. DOI: 10.1007/s10817-008-9103-8.

5. Logical Foundations of Cyber-Physical Systems. Springer International Publishing. 2018. DOI: 10.1007/978-3-319-63588-0. URL: https://doi.org/10.1007/ 978-3-319-63588-0.

6. Martsenyuk V. P., Klos-Witkowska A., Sverstiuk A. S., Bihunyak T. V. On principles, methods and areas of medical and biological application of optical immunosensors. Medical informatics and engineering. 2018. № 2 (42). P. 28-36. DOI: https://dx.doi.org/10.11603/mie.1996-1960.2018.2.9289.

7. Martsenyuk V., Andrushchak I., Zinko P., Sverstiuk A. On Application of Latticed Differential Equations with a Delay for Immunosensor Modeling. Journal of Automation and Information Sciences 2018. Volume 50. Issue 6. P. 55-65. https://doi.org/10.1615/JAutomatInfScien.v50.i6.50

8. Jiang X., Spencer M. G. Electrochemical impedance biosensor with electrode pixels for precise counting of CD4+ cells: A microchip for quantitative diagnosis of HIV infec- tion status of AIDS patients. Biosensors and Bioelectronics. Vol. 25. No. 7. P. 1622-1628. 2010. DOI: 10.1016/j.bios.2009.11.024. URL: https://doi.org/10. 1016/j.bios.2009.11.024.

9. Luppa P. B., Sokoll L. J., Chan D. W. Immunosensors- principles and applications to clinical chemistry. Clinica Chimica Acta. 2001. Vol. 314. No. 1. P. 1-26. ISSN: 0009-8981. DOI: https://doi.org/ 10.1016/S0009-8981(01)00629-5. URL: http://www.sciencedirect.com/science/article/pii/S000989810 1006295.

10. Berger C., Hees A., Braunreuther V., Reinhart G. Characterization of cyber-physical sensor systems. Procedia CIRP. 2016. Vol. 41. P. 638-643. DOI: 10.1016/j.procir.2015.12.019. URL: https://doi.org/ 10.1016/j.procir. 2015.12.019.

11. Soulier P., Li D., Williams J. R., A survey of language- based approaches to cyber-physical and embedded system development. Tsinghua Science and Technology. 2015. Vol. 20. No. 2. P. 130-141. https://doi.org/ 10.1109/TST.2015.7085626

12. URL: https://www.redblobgames.com/grids/hexagons/.

13. McCluskey C. C. Complete global stability for an SIR epidemic model with delay - distributed or discrete. Nonlinear Analysis: Real World Applications. 2010. Vol. 11. No. 1. P. 55-59. DOI: 10.1016/j.nonrwa.2008.10.014. URL: https: //doi.org/10.1016/j.nonrwa.2008.10.014.

14. Nakonechny A., Marzeniuk V. Uncertainties in medical processes control. Lecture Notes in Economics and Mathematical Systems. 2006. Vol. 581. P. 185-192. DOI: 10.1007/3-540-35262-7_11. URL: https://www.scopus.com/inward/record.uri?eid=2-s2.0-53749093113\&doi=10.1007\%2f3-540-352627_11 \&partnerID=40\&md5=03be7ef103cbbc1e94cacbb471daa03f.

15. Marzeniuk V. Taking into account delay in the problem of immune protection of organism. Nonlinear Analysis: Real World Applications. 2001. Vol. 2. No. 4. P. 483-496. https://doi.org/10.1016/S14681218(01)00005-0

16. Prindle A., Samayoa P., Razinkov I., Danino T., Tsim- ring L. S., Hasty J. A sensing array of radically coupled genetic biopixels. Nature. 2011. Vol. 481. No. 7379. P. 39-44. DOI: 10.1038/nature10722. URL: https://doi.org/10.1038/nature10722.

17. Martsenyuk V., Klos-Witkowska A., Sverstiuk A. Stability, bifurcation and transition to chaos in a model of immunosensor based on lattice differential equations with delay. Electronic Journal of Qualitative Theory of Differential Equations. 2018. No. 27. P. 1-31. https://doi.org/10.14232/ejqtde.2018.1.27

18. Hofbauer J. A., Iooss G. A hopf bifurcation theorem for difference equations approximating a differential equation. Monatshefte fur Mathematik. 1984. Vol. 98. № 2. P. 99-113. https://doi.org/10.1007/ BF01637279 


\section{Список використаної літератури}

1. Lee E. A. Cyber physical systems: Design challenges. Center for Hybrid and Embedded Software Systems. URL: https://www2.eecs.berkeley.edu/Pubs/TechRpts/2008/EECS-2008-8.pdf.

2. Lee J., Bagheri B., Kao H.-A. A cyber-physical systems architecture for industry 4.0-based manufacturing systems. Manufacturing Letters. Vol. 3. P. 18-23. 2015. ISSN: 2213-8463. DOI: https://doi.org/10.1016/j.mfglet.2014.12.001. URL: http://www.sciencedirect.com/science/article/pii/S $221384631400025 X$.

3. Kim K.-D., Kumar P. R. Cyber-physical systems: A perspective at the centennial. Proceedings of the IEEE. Vol. 100. No. Special Centennial Issue. 2012. P. 1287-1308. DOI: 10.1109/jproc.2012.2189792. URL: https://doi.org/10.1109/jproc.2012.2189792.

4. Platzer A. Differential dynamic logic for hybrid systems. J. Autom. Reas. 2008. Vol. 41. No. 2. P. $143-$ 189. ISSN: 0168-7433. DOI: 10.1007/s10817-008-9103-8.

5. Logical Foundations of Cyber-Physical Systems. Springer International Publishing. 2018. DOI: 10.1007/978-3-319-63588-0. URL: https://doi.org/10.1007/ 978-3-319-63588-0.

6. Martsenyuk V. P., Klos-Witkowska A., Sverstiuk A. S., Bihunyak T. V. On principles, methods and areas of medical and biological application of optical immunosensors. Medical informatics and engineering. 2018. № 2 (42). P. 28-36. DOI: https://dx.doi.org/10.11603/mie.1996-1960.2018.2.9289.

7. Martsenyuk V., Andrushchak I., Zinko P., Sverstiuk A. On Application of Latticed Differential Equations with a Delay for Immunosensor Modeling. Journal of Automation and Information Sciences 2018. Volume 50. Issue 6. P. 55-65. https://doi.org/10.1615/JAutomatInfScien.v50.i6.50

8. Jiang X., Spencer M. G. Electrochemical impedance biosensor with electrode pixels for precise counting of CD4+ cells: A microchip for quantitative diagnosis of HIV infec- tion status of AIDS patients. Biosensors and Bioelectronics. 2010. Vol. 25. No. 7. P. 1622-1628. DOI: 10.1016/j.bios.2009.11.024. URL: https://doi.org/10. 1016/j.bios.2009.11.024.

9. Luppa P. B., Sokoll L. J., Chan D. W. Immunosensors - principles and applications to clinical chemistry. Clinica Chimica Acta. 2001. Vol. 314. No. 1. P. 1-26. ISSN: 0009-8981. DOI: https://doi.org/ 10.1016/S0009-8981(01)00629-5. URL: http://www.sciencedirect.com/science/article/pii/S0009898101 006295.

10. Berger C., Hees A., Braunreuther V., Reinhart G. Characterization of cyber-physical sensor systems. Procedia CIRP. 2016. Vol. 41. P. 638-643. DOI: 10.1016/j.procir.2015.12.019. URL: https://doi.org/ 10.1016/j.procir.2015.12.019.

11. Soulier P., Li D., Williams J. R., A survey of language- based approaches to cyber-physical and embedded system development. Tsinghua Science and Technology. 2015. Vol. 20. No. 2. P. 130-141. https://doi.org/ 10.1109/TST.2015.7085626

12. URL: https://www.redblobgames.com/grids/hexagons/.

13. McCluskey C. C. Complete global stability for an SIR epidemic model with delay - distributed or discrete. Nonlinear Analysis: Real World Applications. 2010. Vol. 11. No. 1. P. 55-59. DOI: 10.1016/j.nonrwa.2008.10.014. URL: https: //doi.org/10.1016/j.nonrwa.2008.10.014.

14. Nakonechny A., Marzeniuk V. Uncertainties in medical processes control. Lecture Notes in Economics and Mathematical Systems. 2006. Vol. 581. P. 185-192. DOI: 10.1007/3-540-35262-7_11. URL: https://www.scopus.com/inward/record.uri?eid=2-s2.0-53749093113\&doi=10.1007\%2f3-540-352627_11 \&partnerID $=40 \&$ md5=03be7ef103cbbc1e94cacbb471daa03f.

15. Marzeniuk V. Taking into account delay in the problem of immune protection of organism. Nonlinear Analysis: Real World Applications. Vol. 2. No. 4. 2001. P. 483-496.

16. Prindle A., Samayoa P., Razinkov I., Danino T., Tsim-ring L. S., Hasty J. A sensing array of radically coupled genetic biopixels. Nature. 2011. Vol. 481. No. 7379. P. 39-44. DOI: 10.1038/nature10722. URL: https://doi.org/10.1038/nature10722. https://doi.org/10.1016/S1468-1218(01)00005-0

17. Martsenyuk V., Klos-Witkowska A., Sverstiuk A. Stability, bifurcation and transition to chaos in a model of immunosensor based on lattice differential equations with delay. Electronic Journal of Qualitative Theory of Differential Equations. 2018. No. 27. P. 1-31.

18. Hofbauer J. A., Iooss G. A hopf bifurcation theorem for difference equations approximating a differential equation. Monatshefte fur Mathematik. 1984. Vol. 98. № 2. P. 99-113. https://doi.org/10.14232/ ejqtde.2018.1.27 https://doi.org/10.1007/BF01637279 


\title{
УДК 004:94:53:616-073
}

\section{ПОРІВНЯЛЬНИЙ АНАЛІЗ РЕЗУЛЬТАТІВ ЧИСЕЛЬНОГО МОДЕЛЮВАННЯ КІБЕРФІЗИЧНИХ БІОСЕНСОРНИХ СИСТЕМ НА ОСНОВІ РЕШІТЧАСТИХ ДИФЕРЕНЦІАЬНИХ РІВНЯНЬ}

\author{
Андрій Сверстюк
}

\author{
Тернопільський начіональний медичний університет \\ імені І. Я. Горбачевського, Тернопіль, Украӥна
}

\begin{abstract}
Резюме. Проведено порівняльний аналіз результатів чисельного моделювання математичних моделей кіберфізичних біосенсорних систем на гексагональній та прямокутній решітках із використанням решітчастих диференціальних рівнянь. Основна увага приділена математичному опису дискретної динаміки популяцій у поєднанні з динамічною логікою досліджуваних моделей. Запропоновано решітчасті диференціальні рівняння із запізненням у часі для моделювання взаємодї антиген-антитіло всередині гексагональних та прямокутних біопікселів. Використано відповідні просторові оператори, які моделюють взаємодію між біопікселями подібно до явища дифузіі. Представлено результати чисельного моделювання у вигляді зображень фазових площин та решітчастих зображень ймовірності зв'язків антигенів з антитілами в біопікселях моделей кіберфізичних біосенсорних систем для популяиій антитіл відносно популячій антигенів. Проведено порівняльний аналіз результатів чисельного моделювання математичних моделей кіберфізичних біосенсорних систем, які розглянуто в роботі, у вигляді фазових діаграм популяцій антигенів щзодо антитіл та решітчастих зображень ймовірності зв 'язків антигенів із антитілами. Зроблено висновок, щуо при величині сталої запізнення [0, 0.25] для моделі на гексагональній решітці та [0, 0.22] у випадку використання прямокутної решітки відповідно, розв 'язки досліджуваних математичних моделей прагнуть до неідентичних ендемічних станів, які в даному випадку є стійкими фокусами. За отриманими результатами фазових діаграм популяиій антигенів щзодо антитіл та решітчастих зображень ймовірності зв'язків антигенів з антитілами в біопікселях кіберфізичних біосенсорних систем зроблено висновок, щу при величині сталої запізнення 0,25 (у випадку гексагональної решітки) та 0.23 (у випадку прямокутної решітки) виникає біфуркація Хопфа й усі подальші траєкторії відповідають стійким граничним ичклам для всіх пікселів. Отримані експериментальні результати дають змогу провести порівняльний аналіз стійкості математичних моделей кіберфізичних біосенсорних систем на гексагональній та прямокутній решітках із використанням решітчастих диференціальних рівнянь.

Ключові слова: кіберфізична система, біосенсор, неперервна динаміка, динамічна логіка, диференціальні рівняння.
\end{abstract}

